\title{
FÖLDRENGÉSI SZABVÁNYOK FEJLŐDÉSE ÉS ALKALMAZÁSA ERDÉLYBEN
}

\section{THE EVOLUTION AND PRACTICE OF SEISMIC CODES IN TRANSYLVANIA}

\author{
Gobesz F. Zsongor ${ }^{1}$, Kegyes Csaba ${ }^{2}$ \\ ${ }^{1}$ Kolozsvári Müszaki Egyetem, Épitömérnöki Kar, Tartószerkezet-mechanikai Tan- \\ szék, Románia, 400020 Cluj-Napoca, C. Daicoviciu u. 15, V. épület, III/305; Telefon \\ / Fax: +40-264-401351, levelezési cím: go@mecon.utcluj.ro \\ ${ }^{2}$ PIUS Épitészeti, Mérnöki és Számítástechnikai Kft, Magyarország, 9024 Győr, Hu- \\ nyadi u. 18; Telefon / Fax: +36-96-411568, levelezési cim: kcsl@pius.hu
}

\begin{abstract}
In terms of seismic safety, the knowledge of the given field's seismicity is a fundamental issue. The earthquakes in the Carpathian Basin are known since 463, Transylvania is a part of this region. At the end of 1800's the researchers have discovered that in those places where an earthquake happened, the occurence of another similar or stronger quake is very likely. The evolution of the seismic design codes during time is mainly determined by the technical-economic development. Knowing the history of standards and their application, the current requirements of seismic safety regulations and concepts can be understood and implemented in a better way.
\end{abstract}

Keywords: seism, code, evolution, practice, Transylvania.

\section{Összefoglalás}

A földrengés elleni védekezésben alapvető kérdés az adott terület szeizmicításának ismerete. A Kárpát-medence földrengései 463-tól ismertek, Erdély egy része ennek a területnek. Az 1800-as évek végén a kutatók felismerték, hogy ahol egy földrengés volt, ott valószínü legalább olyan erősségü földrengés bekövetkezése. Az esztendők folyamán a földrengésméretezési szabványok alakulását főleg a müszaki-gazdasági fejlődés határozta meg. Ismerve a földrengési szabványok és alkalmazásaik történetét, jobban meg lehet érteni a jelenlegi fogalmakat és az érvényes elöírások követelményeit, és hatékonyabban lehet őket alkalmazni.

Kulcsszavak: földrengés, szabvány, fejlödés, alkalmazás, Erdély.

\section{Bevezetés}

Erdély földrengés-veszélyeztetettsége szorosan összefügg a Kárpát-medence szeizmicitásával (1. ábra). A Kárpátmedence (helyenként Pannon-medencének is nevezik, bár ez utóbbi tulajdonképpen egy alegység) geológiailag a néhai Tethys óceán egyik üledékgyüjtő medencéje, melyből az alpi orogén fázis során kiemel- kedtek a Kárpátok. Nyugatra a DK-Alpok, délre a Dinári-hegység, északra és keletre a Kárpátok hajlatai határolják. A medencealjzat sávos, parkettaszerü szerkezete több lemezdarabból áll össze, melyek részben összeforrtak, és már inaktívak. Felépítésében elsősorban fiatalabb (neogén és kvarter) medenceülledékek vesznek részt, amelyekből mintegy szigetként állnak ki a túlnyomóan mezozós kőzetekből és neogén 
vulkanitokból álló hegységek. A földtörténeti elözmény egyfelől a domborzati sajátosságok kialakulásáért felelős, másfelöl viszont meghatározza azt a gazdag nyersanyagbázist, amellyel a Kárpát-medence rendelkezik. A só mellett jelentős érctelepek alakultak ki. Első ütemben a BelgrádTemesvár-Kolozsvár vonalban, azután Pécs -Debrecen illetve Zagráb-Miskolc sávban, majd a szinorogén fázis ugyanezt a mozgás irányt követte Belgrád-Nagyvárad és Balaton-Darnó vonalban. Ezek a jura - alsó kréta idejére tehetők, összefüggésben a Tethys felnyílásával, a húzóerők és a tértágulás okozta árkos beszakadások és térszínsüllyedés miatt. A korábbi, triász vulkanizmust a diabáz, gabbró és kvarcporfír elöfordulása jelzi.

A kárpáti vulkáni ív tagjai nyugatról kelet felé egyre fiatalodnak, nagyjából hasonlóan a forrópontos vulkanizmushoz. Nem a lemez forrópont feletti mozgása okozta, hanem a felszakadó törésvonalak aktivitásának eltolódása. Ezt a vulkanizmus jellege igazolja: nem híg bazaltos, kiömléses tevékenység folyik, amely pajzsvulkánokat hoz létre, hanem andezites összetételü, robbanásos kitörést produkáló. A KeletiKárpátokban a mai napig megfigyelhetők egyes vulkáni utómúködések, gáz- és gőzkifúvások, illetve szénsavas borvízfeltörések. A középhegységi területeken pedig sok helyen magas a geotermikus energia szintje, amely hévizes feltörésekkel jár együtt. A pliocénben a Paratethyst szegélyező „frissen” kiemelkedett hegyvidék szolgáltatta a Dés-Brassó, Eperjes-Radna vonalakon, valamint a Felvidék nagy részén található nemesfémbányák készleteit létrehozó vulkanizmust.

A földrengések általában a törésvonalak, azaz a nagyobb lemezhatárok mentén robbannak ki. A Kárpát-medence szeizmicitása mérsékeltnek tekinthető a széleihez képest, az Erdélyre jellemző földrengések pedig sekély és közepes fészekmélységböl (15$200 \mathrm{~km}$ ) törnek fel.
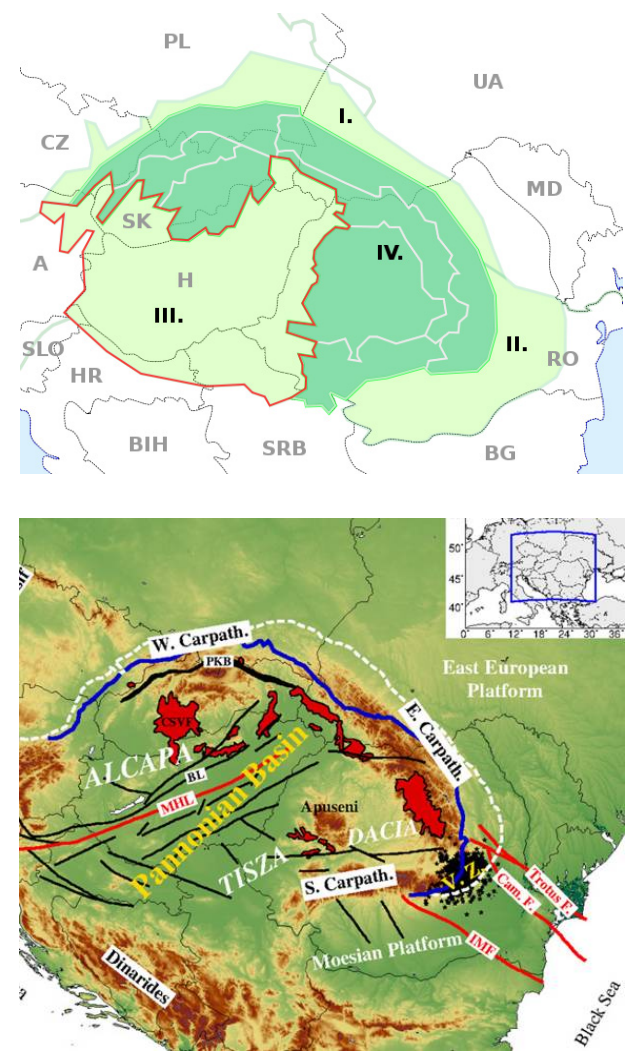

1.ábra. Felső: a Kárpát-medence (I. Kárpátala, II. - Román alföld, III. Pannón-medence, IV. - Kárpátok beltere) [4]. ALsó: a Kárpát-medence felszini szerkezete (pirossal a vulkánitos réteg, $M H L$ - a középmagyar vonal, IMF - az bel-moéziai törésvonal, Cam.F. - Camena törés, V.Z. - Vráncsa) [11].

\section{Történelmi áttekintés}

$\mathrm{Az}$ európai földrengések mérését már az ókori görögök is megkísérelték. Az egyik legrégebbi skálát Jacopo Gastaldi piemonti térképrajzoló dolgozta ki az 1594-es Nizza környéki földrengéskor [12]. Eleinte négy fokozatot jeleztek, de a XIX. században már tíz fokozatú skálát használtak. A Mercalliféle 10 fokú skálát Cancani 1904-ben 12 fokúra bővítettte, figyelembe véve a talajmozgást (gyorsulást) is az intenzitás mel- 
lett. Sieberg ezt tökéletesítette az épületekre mért hatások osztályozásával, és így lett 1917-ben nemzetközi mérceként elfogadva.

A Kárpát-medencében a földrengések összeírása tulajdonképp Grossinger János komáromi jezsuita 1783-ban megjelent munkájával kezdődött. Öt követte Kitaibel Pál és Tomtsányi Ádám 1814-ben megjelent munkája az 1810-es móri földrengésről (az első izoszeiszta térképpel), majd 1858ban Kornhuber, Schmidt és Hunfalvy, illetve 1869-be Jeitteles dolgozatai a zsolnai földrengésről. Az 1880-as erdélyi földrengésről Koch és Schuster készített tanulmányt 1881-ben, míg a szintén az évi zágrábi földrengést Hantken, Torbar (1882) és Wahner (1883) értékelték tanulmányaikban. Edward Suess 1897-ben jelentette meg monográfiáját az 1895-ös ljubljanai földrengésről.

Egy terület szeizmicitásának, földrengés-veszélyességének vizsgálata a múltban keletkezett földrengések számbevételét jelenti. A Kárpát-medence környezetében a történelem során változó határokkal elhelyezkedő országok közül Magyarország az az állam, mely a történelmi földrengések legteljesebb Kárpát-medencei adatbázisát elsőként kiépíti. A Magyarhoni Földtani Társulat 1881-ben létrehozta a Földrengési Bizottságot, melynek kiemelkedő tagjai Kövesligethy Radó és Schafarzik Ferenc hozzájárultak, hogy 1914-ig Magyarország kiépítette azt az állomáshálózatot, mellyel a szeizmológiai kutatás élvonalába tartozott. Ezek az állomások: Budapest, Kolozsvár, Temesvár, Szeged, Belgrád, Pécs, Zágráb, Fiume, Kalocsa, Kecskemét, Ógyalla, Ungvár helységekben felállított mérőmüszerekböl álltak.

Az erdélyi földrengések adatai több katalógusban is szerepelnek. A négy legismertebb magyar földrengés-katalógus (Réthly, 1952; Csomor és Kiss, 1962; Zsíros, Mónus és Tóth, 1988; Zsíros, 2000) közül a Zsíros Tiboré a legjelentősebb, mert 20478 bejegyzést tartalmaz a 455-1995-ös évek idő- szakából szinte a teljes Kárpát-medencére. E 20478 földrengés közül 3751-nek ismert a fészekmélysége, melynek a meghatározását a Kövesligethy-féle képlet adja:

$$
\begin{gathered}
I_{0}-I_{k}=3 \cdot \log \left(D_{k} / h\right)+3 \cdot \alpha \cdot \log (e) \cdot\left(D_{k}-h\right) \\
D_{k}^{2}=R_{k}^{2}+h^{2}
\end{gathered}
$$

A fenti képletekben $I_{0}$ az epicentrális intenzitás, $I_{k}$ az intenzitás értéke a $D_{k}$ hipocentrális távolságban, $R_{k}$ az izoszeiszta sugárértéke, $h$ a fészekmélység és $\alpha$ az abszorbciós együttható. A magnitúdó érték a rengések olyan méret szerinti osztályozása, mely a földrengéshullámok müszeres regisztrátumai alapján történik. A Kárpátmedencében, így Erdélyben is, az Ambraseys által felállított gyorsulásgyengülési modellt használták az adott helyen a számításba vehető gyorsulás becslésére:

$$
\log \left(a_{h}\right)=-1,39+0,266 \cdot M_{S}-0,922 \log (D)
$$

$M_{S}$ a felületi, főleg Rayleigh-hullámból meghatározott magnitúdó; $M_{B}$ a kompreszsziós (primer) térhullámból meghatározott magnitúdó; $M_{L}$ a kéreg-, azaz Lovehullámból meghatározott (úgynevezett Richter) magnitúdó; $M_{D}$ pedig a szeizmogramon mért időtartamból becsült magnitúdó. Ezek között a következő összefüggések léteznek [13]:

$$
\begin{aligned}
& M_{S}=0,97( \pm 0,05) M_{B}+0,04( \pm 0,24) \\
& M_{S}=0,86( \pm 0,06) M_{L}+0,57( \pm 0,27) \\
& M_{S}=1,21( \pm 0,11) M_{D}-1,23( \pm 0,52) \\
& M_{B}=0,59( \pm 0,05) M_{L}+1,75( \pm 0,22) \\
& M_{B}=0,90( \pm 0,08) M_{D}+0,20( \pm 0,32) \\
& M_{L}=1,14( \pm 0,02) M_{D}-0,69( \pm 0,06)
\end{aligned}
$$


Az $M$ átlagos müszeres magnitúdó a felszabadult energiát jellemzi, és függ az $I_{0}$ epicentrális intenzitástól, valamint a $h$ fészekmélységtől:

$$
M=a \cdot I_{0}+b \cdot \log (h)+c .
$$

Amennyiben a Kárpát-medencét a $44.0 \mathrm{~N}-50.0 \mathrm{~N}$ és $13.0 \mathrm{E}-28.0 \mathrm{E}$ földrajzi koordináták közé eső területként értjük, akkor elfogadott az alábbi:

$M=0,68( \pm 0,02) \cdot I_{0}+0,96( \pm 0,07) \cdot \log (h)-$ $-0,90( \pm 0,10)$.

Háromszék-Vráncsaföldet a $44.5 \mathrm{~N}-$ $46.5 \mathrm{~N}$ és $25.5 \mathrm{E}-28.0 \mathrm{E}$ földrajzi koordináták közötti területre vetítve, a magnitúdó értéke:

$M=0,52( \pm 0,02) \cdot I_{0}+0,55( \pm 0,11) \cdot \log (h)+$ $+1,18( \pm 0,20)$.
Egy térségben a várható földrengések száma egyenes arányban van a magnitúdó értékükkel (Gutenberg-Richter-összefüggés):

$$
\log N=a+b \cdot M \text {. }
$$

A földrengések által felszabadult rugalmas energia becslését a Gutenberg-Richterösszefüggéssel lehet elvégezni, ahol az $E$ vel jelölt energia Joule-ban értendő:

$$
\log (E)=1,5 \cdot M+4,8 \text {. }
$$

A Kárpát-medence földrengésveszélyességét a Cornell (1968) által kidolgozott módszerrel határozták meg, mely figyelembe veszi a várható földrengések forrásterületeit, a tapasztalt gyakoriságot, a veszélyeztetettségi paramétereket (csúcsgyorsulás, földrengés-intenzitás) és azok távolság-szerinti gyengülését, illetve az ismert forrásterületeken az adott gyakorisággal keletkező földrengések hatásának számítását az adott gyengülés figyelembevételével.

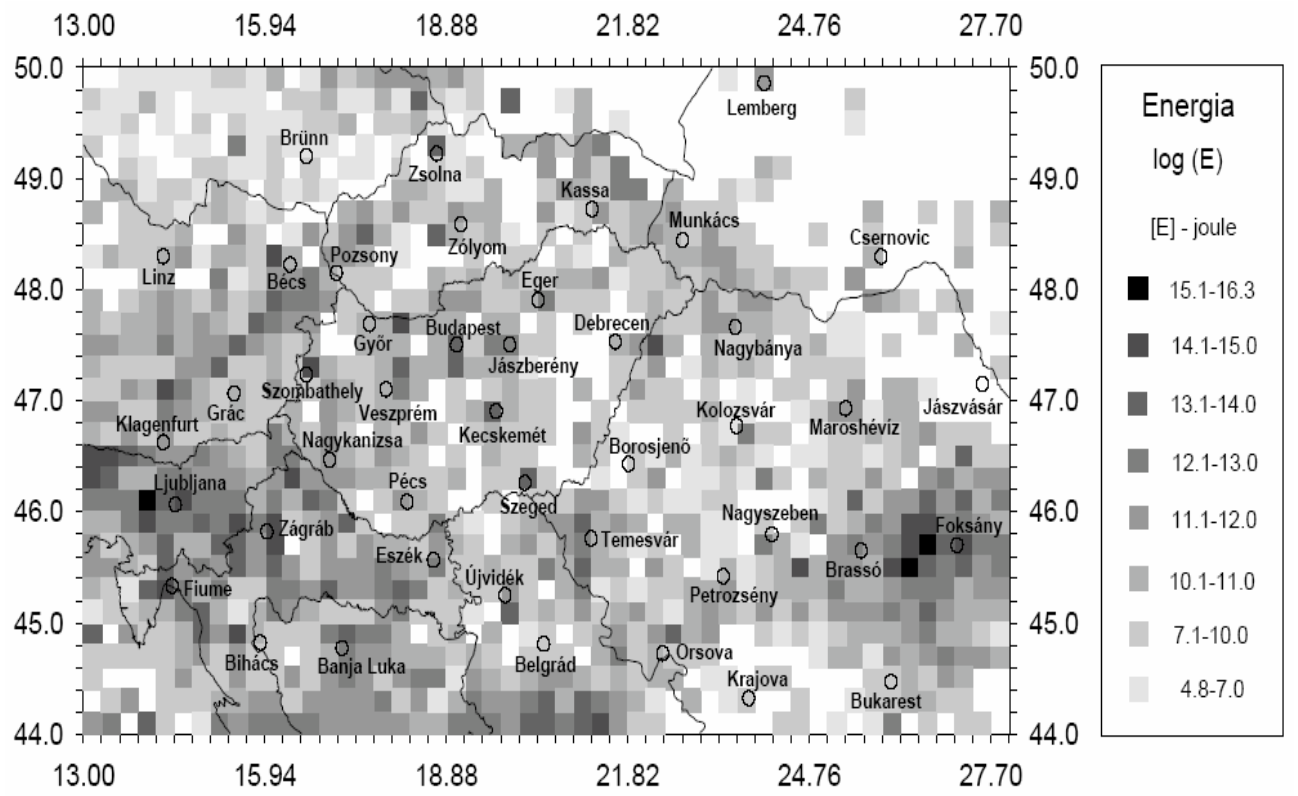

2. ábra. A földrengések által felszabadult energia területi eloszlása a Kárpát-medencében [13] 
1. táblázat. Válogatás az 1100-1995 között észlelt legnagyobbb magnitudójú erdélyi földrengésekböl [13].

\begin{tabular}{|c|c|c|c|c|}
\hline Dátum & Epicentrum koord. & $M$ & $I_{0}$ & Helység \\
\hline 1196.02 .13 & $45,70 \mathrm{~N} ; 26,60 \mathrm{E}$ & 6,4 & 8,0 & Vráncsaföld \\
\hline 1230.05 .10 & $45,70 \mathrm{~N} ; 26,60 \mathrm{E}$ & 6,7 & 8,5 & Vráncsaföld \\
\hline 1327 & $45,70 \mathrm{~N} ; 26,60 \mathrm{E}$ & 6,4 & 8,0 & Vráncsaföld \\
\hline 1446.10 .10 & $45,70 \mathrm{~N} ; 26,60 \mathrm{E}$ & 6,7 & 8,5 & Vráncsaföld \\
\hline 1471.08 .29 & $45,70 \mathrm{~N} ; 26,60 \mathrm{E}$ & 6,4 & 8,0 & Vráncsaföld \\
\hline 1516.11 .24 & $45,70 \mathrm{~N} ; 26,60 \mathrm{E}$ & 6,9 & 9,0 & Háromszéki-havasok \\
\hline 1545.07 .19 & $45,70 \mathrm{~N} ; 26,60 \mathrm{E}$ & 6,4 & 8,0 & Háromszéki-havasok \\
\hline 1569.08 .17 & $45,70 \mathrm{~N} ; 26,60 \mathrm{E}$ & 6,4 & 8,0 & Háromszéki-havasok \\
\hline 1590.08 .10 & $45,70 \mathrm{~N} ; 26,60 \mathrm{E}$ & 6,7 & 8,5 & Háromszéki-havasok \\
\hline 1595.04 .21 & $45,60 \mathrm{~N} ; 26,00 \mathrm{E}$ & 6,4 & 8,0 & Barcaság \\
\hline 1604.05 .03 & $45,70 \mathrm{~N} ; 26,60 \mathrm{E}$ & 6,4 & 8,0 & Háromszéki-havasok \\
\hline 1605.12 .24 & $45,70 \mathrm{~N} ; 26,60 \mathrm{E}$ & 6,4 & 8,0 & Vráncsaföld \\
\hline 1606.01 .13 & $45,70 \mathrm{~N} ; 26,60 \mathrm{E}$ & 6,2 & 7,5 & Háromszéki-havasok \\
\hline 1620.11 .08 & $45,80 \mathrm{~N} ; 26,60 \mathrm{E}$ & 6,7 & 8,5 & Vráncsaföld \\
\hline 1701.06.12 & $45,70 \mathrm{~N} ; 26,60 \mathrm{E}$ & 6,2 & 7,5 & Vráncsaföld \\
\hline 1738.06 .11 & $45,70 \mathrm{~N} ; 26,60 \mathrm{E}$ & 6,7 & 8,5 & Vráncsaföld \\
\hline 1790.04 .06 & $45,70 \mathrm{~N} ; 26,60 \mathrm{E}$ & 6,4 & 8,0 & Vráncsaföld \\
\hline 1793.12 .08 & $45,70 \mathrm{~N} ; 26,60 \mathrm{E}$ & 6,4 & 8,0 & Háromszéki-havasok \\
\hline 1802.10 .26 & $45,70 \mathrm{~N} ; 26,60 \mathrm{E}$ & 7,2 & 9,5 & Háromszéki-havasok \\
\hline 1829.11 .26 & $45,70 \mathrm{~N} ; 26,60 \mathrm{E}$ & 6,4 & 8,0 & Vráncsaföld \\
\hline 1838.01 .23 & $45,70 \mathrm{~N} ; 26,60 \mathrm{E}$ & 6,9 & 9,0 & Háromszéki-havasok \\
\hline 1868.11 .13 & $45,70 \mathrm{~N} ; 26,60 \mathrm{E}$ & 6,2 & 7,5 & Háromszéki-havasok \\
\hline 1903.09.13 & $45,12 \mathrm{~N} ; 26,54 \mathrm{E}$ & 6,0 & 6,5 & Háromszéki-havasok \\
\hline 1908.10.06 & $45,50 \mathrm{~N} ; 26,50 \mathrm{E}$ & 6,8 & 8,0 & Háromszéki-havasok \\
\hline 1929.11 .01 & $45,90 \mathrm{~N} ; 26,50 \mathrm{E}$ & 6,2 & 6,5 & Háromszék \\
\hline 1934.03 .29 & $45,80 \mathrm{~N} ; 26,50 \mathrm{E}$ & 6,6 & 8,0 & Vráncsaföld \\
\hline 1940.10 .22 & $45,76 \mathrm{~N} ; 26,42 \mathrm{E}$ & 6,2 & 7,0 & Háromszék \\
\hline 1940.11 .10 & $45,77 \mathrm{~N} ; 26,73 \mathrm{E}$ & 7,3 & 9,0 & Vráncsaföld \\
\hline 1945.09 .07 & $45,90 \mathrm{~N} ; 26,50 \mathrm{E}$ & 6,5 & 7,5 & Vráncsaföld \\
\hline 1945.12 .09 & $45,70 \mathrm{~N} ; 26,80 \mathrm{E}$ & 6,1 & 7,0 & Vráncsaföld \\
\hline 1977.03.04 & $45,77 \mathrm{~N} ; 26,76 \mathrm{E}$ & 7,2 & 9,0 & Vráncsaföld * \\
\hline 1986.08 .30 & $45,54 \mathrm{~N} ; 26,31 \mathrm{E}$ & 6,9 & 8,0 & Háromszéki-havasok \\
\hline 1990.05 .30 & $45,85 \mathrm{~N} ; 26,66 \mathrm{E}$ & 6,6 & 8,0 & Háromszéki-havasok \\
\hline 1990.05 .31 & $45,81 \mathrm{~N} ; 26,77 \mathrm{E}$ & 6,1 & - & Vráncsaföld \\
\hline
\end{tabular}

* Jelentős károkat okozott Bukarestben.

\section{A méretezési előírások fejlődése}

A földrengések kutatásaival gyakran egy időben készítették el azokat a méretezési módszereket, melyek gyüjtőnéven konvencionális statikus eljárások címen szere- pelnek. Az 1800-as évek végén minden kutató felismerte, hogy ahol volt földrengés, ott valószínű majd legalább olyan erősségü földrengés bekövetkezése. Simon [9] idézi Sieberg számítását is, annak a kutatónak eljárását, akinek nevéhez nemcsak az intenzitás skála kapcsolható (Mercalli- 
Cancani-Sieberg-féle intenzitási skála), hanem az első rázóasztal is. Ezen a rázóasztalon felépített falazott szerkezet modellje bizonyította elképzeléseinek helyességét, miszerint ,a négyzetes oszlop alakú test eltörik", ha az $a_{1}$ gyorsulás:

$$
a_{1}=\frac{J \cdot g \cdot Z}{b \cdot h \cdot G \cdot P} .
$$

$J$ a tehetetlenségi momentum, $g$ a nehézségi gyorsulás, $Z$ a húzószilárdság, $b$ az eltört felület oldalhosszának a fele, $h$ a letört rész súlypontjának a magassága a törési felület felett, $G$ a test térfogategységének súlya, $P$ pedig a letört rész térfogata. A szeizmikus terhet úgy számították, hogy az épület függőleges tengelye egyenes marad, függetlenül a rezgésektől és a merevségtől. Az épület súlyát egyenletesen megoszlónak tekintették, akárcsak a gyorsulást:

$$
H_{i}\left(S_{i}\right)=\frac{Q_{i}}{g} \cdot a_{i}=c \cdot Q_{i} .
$$

Kétféle tehetetlenségi erőt különböztettek meg ( $S=k \cdot P$, ahol, $k$ a szeizmikus tényezö, $P$ a súlyterhelés): hosszú periódusú rezgések, illetve rövid periódusú rezgések szeizmikus tehetetlenségi erőit. A hosszú periódusú rezgések tehetetlenségi erőit az épületek és létesítmények egészének és részeinek (épületvázak, falak, oszlopok, tornyok, gyárkémények, világítótornyok, támfalak) szilárdsági és állékonysági számításai során vették figyelembe (épület elemeinek önsúlya, födémekre háruló terhelés, daruk önsúlya, hóterhelés stb.). A rövid periódusú rezgések szeizmikus tehetetlenségi erőit csak a merev lehorgonyzások (oszlopok, rácsostartók, gerendák lehorgonyzásánál) nyírásra történő számításakor vették figyelembe. A más erőkkel való terhelésekkel együtt fellépő szeizmikus erők a különleges behatásokhoz tartoztak, ezért a szeizmikus erőkre való számításkor a legkisebb biztonsági tényezőt vették figyelembe.
A számítások a földrengés intenzitásához voltak kötve.

A dinamikus méretezési elmélet később jelent meg, ez a szemlélet figyelembe veszi a talajmozgást (gyorsulás, frekvencia), az altalaj minőségét, a szerkezet dinamikus válaszát (merevség, szilárdság, csillapítás, duktilitás). A talajgyorsulás nagyságát az intenzitásokhoz kötötték (ma az Európai Makroszeizmikus Skála érvényes, melyet összehangoltak az EC8-cal). A talajmozgást a szeizmogram írja le, amely a talajelmozdulást ábrázolja az idő függvényében: $1 \mathrm{gal}=1 \mathrm{~cm} / \mathrm{s}^{2}$. A szeizmogram általában szabálytalan diagram, bár van bizonyos periodicitása. Bármelyik földrengés út-, sebesség- és gyorsulásdiagramját vizsgáljuk, mindig meghatározható egy periódusidő. A földrengés bekövetkezési valószínüsége, magnitúdója, intenzitása mind a geológiai adottságoktól függ. A méretezéshez szükséges gyorsulást a szeizmológiai kutatások által összeállított valószínüségi térképek adják. Az altalaj minőségi hatását befolyásolja a felső laza rétegek által jelentkező szürőhatás, mely a saját frekvenciatartományt növeli, az ettől távol lévőt csökkenti. Ismert, hogy a felső néhány tíz méteres talaj a felszínen kialakuló gyorsulásokat jelentősen módosítja. A helyi hatás figyelembevételéhez szükséges a laza rétegek transzverzális sebességének függvényében az úgy nevezett helyi módosító tényező meghatározása. Ez lebontható településekre vagy nagyobb területre, mikro- és makrozónákra.

Az építménynek a földrengés következtében fellépő mozgását, a szerkezet válaszát döntő módon befolyásolja a saját frekvenciája és a csillapítás. Egy szerkezet sajátfrekvenciája függ a tömegeloszlástól és a merevségi tulajdonságoktól. A több szabadságfokú rendszer esetében mindegyik saját rezgés alak más-más kritikus csillapításának a hatékonysága is függ a sajátrezgés alakjától. Az épületek méretezése azon az elven alapszik, hogy feltételezték, hogy a szerke- 
zet rugalmasan viselkedik, a sajátrezgések ortogonálisak, így a rengésnek az egyes sajátrezgés-alakokra gyakorolt hatását külön-külön, egymástól függetlenül vizsgálhatták. A földrengés az épületet, építményt alsó részének a talajjal érintkező felületén gerjeszti. A dinamikus elmélet fejlődése és az El Centro-i földrengés feldolgozása lehetőséget adott egyszerüsített számításhoz. A szerkezet maximális gyorsulása függ a szerkezet sajátrezgésének periódusidejétől, a maximális talajgyorsulástól, a szerkezeti csillapítástól, duktilitásától és az altalaj tulajdonságától. A szeizmogramra különböző válaszokat jelentő görbesereget burkoló görbe (az úgynevezett $\beta=a_{\max }^{\text {szerk }} / a_{\max }^{\text {talaj }}$ görbe), mely a számítások egyszerüsítéséhez vezetet elősegítette, hogy a kapott maximális szerkezetgyorsulásból meghatározható legyen az egyes tömegpontok gyorsulása, az $i$ sajátrezgés-alak szerint:

$$
\eta_{i k}=\frac{x_{i k} \cdot \sum_{k=1}^{n} Q_{k} \cdot x_{i k}}{\sum_{k=1}^{n} Q_{k} \cdot x_{i k}^{2}}
$$

Ez az eljárás a modális analízis, azaz minden rezgésmódra meghatározható a sajátvektor alakja. A kezdeti statikus elméletet felváltó dinamikus szemléletből, vagyis az alakváltozási formát figyelembe vevő megoldásokból születtek azok a szabványok, melyek az 1970-es éveket jelentik.

A fellelhető források szerint úgy tünik, hogy az 1940. november 10. -i nagy földrengésig Romániában nem volt hivatalos méretezési elöírás. Addig inkább olasz, német, angol vagy francia elöírások alapján méreteztek szeizmikus hatásokra, főleg statikus számításokat végezve. Az első, az 1941-ben megjelent (Közmunkák és Távközlési Minisztérium által kiadott) 84351/1941.12.30 jelölésü határozat volt „Ideiglenes elöírás a földrengés okozta károsodás megelőzésére és a károsodott épü- letek visszaállítására” címmel. Ezt követte az „Útmutató földrengések okozta károk megelőzésére" (Közmunkák és Távközlési Minisztérium 60173/1945.05.19 számú előírása, melyet a Legfelső Müszaki Tanács is jóváhagyott) címü anyag. Érdekes és említésre méltó, hogy 1958-ban elkészült egy szabvány (STAS 2923-58), ami nem került jogeröre, és így alkalmazva sem volt. Ez a szabvány jóval bővebb volt, mint a későbbi P.13-as hivatalos elöírás. Időközben ismert volt az amerikai (Californian Code) és a szovjet elöírás ( $\mathrm{SN} \mathrm{8-50)}$ is.
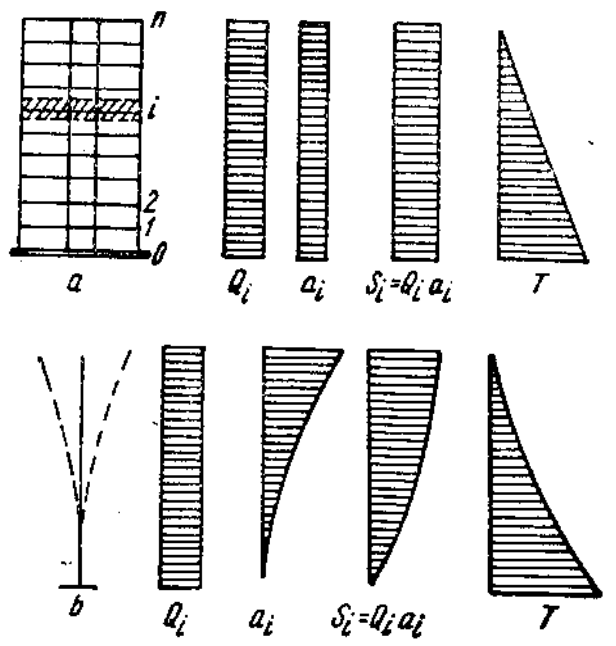

3. ábra. Egyenletes tömegeloszlás és gyorsulás a P.13 elött (a) és a P.13-63-ban szereplö módositás (b)

A P.13-63 1963. július 18. -án lett közzétéve. Ez volt az első „dinamikus” számításra vonatkozó hivatalos elöírás melyben figyelembe vették a zóna szeizmikus fokát és az épület fontosságát is. A szeizmikus erők várható nagyságát az intenzitásokhoz kötötték (ezt a STAS 3684-63 elöírás tartalmazta) és az ország térképén feltüntették a 7., 8. és 9. intenzitású területet. A számításba vett szeizmikus erő a következőképp volt számítható (ismerve a $K_{S}$ együtthatót, ami a szeizmikus övezet függvénye, a $\beta$ 
dinamikai jellemzőjét a szerkezetnek, ami a $T$ sajátrezgési periódustól és az alapozási rétegtöl függ, meg a $\psi$ csillapítási együtthatót): $S=c \cdot Q=K_{S} \cdot \beta \cdot \varepsilon \cdot \psi \cdot Q=\sum_{i}^{n} S_{k}$, ahol $c=K_{S} \cdot \beta \cdot \varepsilon \cdot \psi$

Az ekvivalenciát jelentő (a több szabadságfokú épületszerkezet megfelelösége az egy szabadságfokúval) $\varepsilon$ együttható az alábbi képlettel volt számítható (a gravitációs terhek számításánál figyelembe kellett venni a terhelési tényezőt is, mely táblázatban volt megadva):

$$
\varepsilon=\frac{\left[\sum_{1}^{n} Q_{k} \cdot u_{k}\right]^{2}}{\left[\sum_{1}^{c} Q_{k}\right] \cdot\left[\sum_{1}^{n} Q_{k} \cdot u_{k}^{2}\right]}
$$

A földrengésből ébredő vízszintesen müködő alapnyíróerőt a tömegekkel arányosan kellet szétosztani. Az egyszerüsített számításnál szükséges kezdeti feltétel az volt, hogy a (18)-as képletben szereplö $c$ globális szeizmikus együttható értéke ne legyen 0,02 alatt. A szerkezet föbb teherviselő elemeinek ellenőrzése a földrengésből ébredő függőleges erőkre szintén elő volt írva, ehez a szabvány százalékos növekményeket adott. A nem szerkezeti elemeket is ellenőrizni kellett földrengési hatásokra, növekménnyel meghatározott saját súlyt véve figyelembe.

Hat év után került sor az elöírás módosítására, P.13-70 jelöléssel. Ebben, a legfontosabb a $K_{S}$ intenzitás függvényü együttható és a $\beta$ dinamikai jellemzők változása volt, bevezetve egy új (az alapozási réteget jellemzö) együtthatót is az intenzitászónák gyarapítása mellett. Az $\varepsilon$ ekvivalencia együtthatónál figyelembe lehetett venni a magasabb rezgésformákat, de az első rezgésmódnál szintén be kellett tartani a $0,02-$ es határértéket a $c$ globális együtthatónál.
Magas, hajlékony szerkezetek (önálló kémények, toronyszerü építmények) esetében legalább három rezgésformát kellett figyelembe venni. Az elöírás egyik legfontosabbnak bizonyult része az volt, amelyik a szomszédos építmények közötti hézag számítását írta elő (hogy földrengés hatására keletkező kilengések folyamán ne ütközzenek). Az 1977. március 4. -i földrengés tanulságai új szemlélethez és új előírásokhoz vezettek. Az 1940. novemberi és 1977. márciusi földrengések tanulmányozása vezetett az újabb szeizmikus zónák körülhatárolásához Romániában (izo-szeiszta térkép a STAS 1 1100/1-77 szabványban), ezek a tapasztalatok a későbbi előirásokban is hasznosítva lettek.

A P.100 bevezetésével 1978-ban (P.100-78) sok minden megváltozott. Igaz, hogy a fontossági osztálybesorolás nem változott, ellenben új intenzitási zónákat és ezeknek megfelelö együtthatókat iktatott be, változtatva a rezgésmódokon is. A szomszédos épületek közötti hézag számítá$\mathrm{sa}$ is figyelembe vette a magasabb rezgésmódokat. Az emeleti alakváltozás (relatív kihajlás) korlátozását a szintmagasság 1/200-ad, illetve 1/150-ed részében állapították meg. A P.100-81 lényegileg csupán a 6. zónának megfelelő $k_{s}$ tényezőt módosította a P.100-78-hoz képest. Kilenc év után jelent meg egy modernebb P.100 (P.10090), melyben a földrengések átlagos visszatérési intervallumát (románul IMR) 50 évre vették.

A P.100-90 és a P.100-92 alig különbözött egymástól, mindkettőben két térkép volt: az egyik a $T c(0,7 s 1,5 s$ és $1.5 s)$ sarokperiódusok segítségével a helyi hatásokat vitte be a számításokba, a másik pedig az új (A, B, C, D, E, F) védettségi zónákra elöírt $K_{s}$ szeizmikus intenzitási együtthatót $(0,32$ az A zónában; 0,25 a B; 0,20 a C; 0,16 a D; 0,12 az E és 0,08 az $\mathrm{F}$ zónában) - 4.b. ábra. 


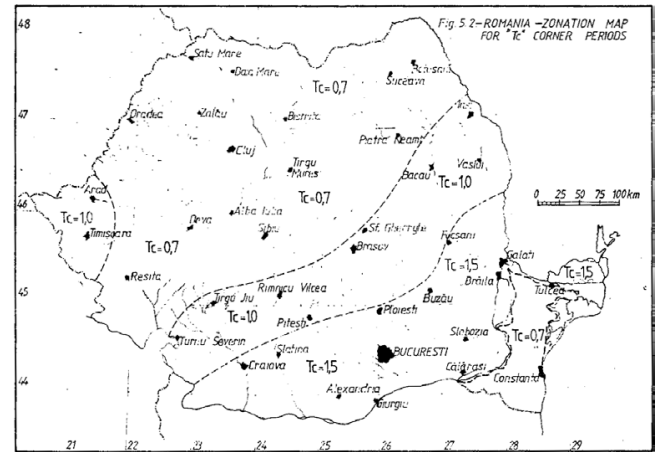

a.

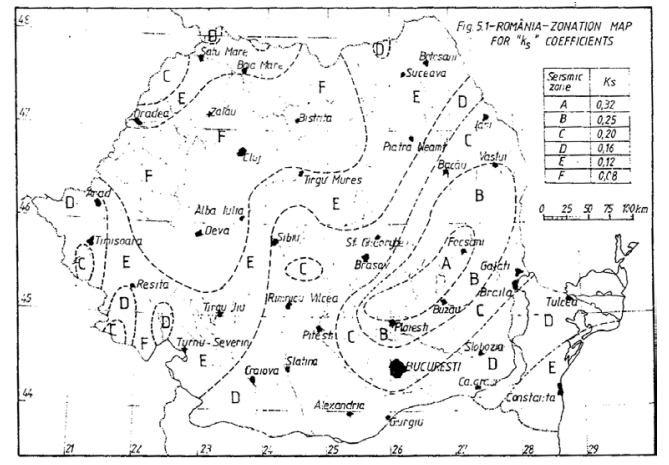

b.

4. ábra. A P.100-90-ben megjelent új térképek (a. A jellemzö Tc sarokperiódusok; $b$. A védettségi zónákhoz tartozó $K_{s}$ együtthatók) [7].

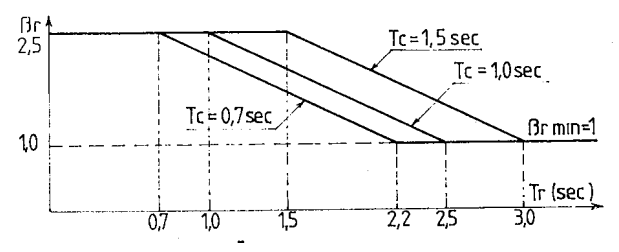

a.

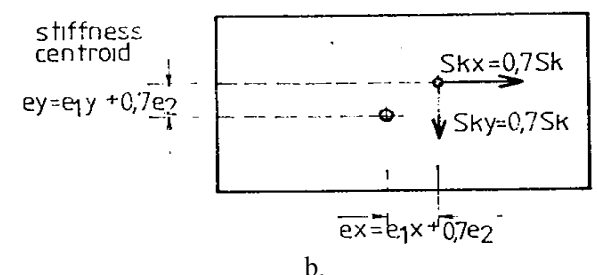

5. ábra. A P.100-90-ben megjelent $b$ görbe (a), valamint a járulékos külpontosság figyelembevétele (b) [7].
A $\beta$ dinamikus tényező is át lett alakítva, a görbe alakja is megváltozott (5.a. ábra). A rezgésmódnak megfelelő $\varepsilon_{i}$ alaki tényezőt a tömeg és a lengésforma függvényében kellett számítani. A merevségi és tömegközpontok eltérése csavaró rezgéshez vezet, ha mindkét fő irányban egyidejűnek tekintik a külpontosságokat, akkor a földrengésből származó alap nyíróerőket csökkenteni lehet. A szerkezet torzulását okozó csavarónyomatékot járulékos külpontossággal növelt külpontoságból lehet meghatározni $\left(M=S \cdot e\right.$, ahol $e=e_{1} \pm e_{2}, e_{1}$ a merevségi és a tömegközpont közötti távolság, $e_{2}$ pedig a járulékos külpontosság, 5.b. ábra). A csillapítási tényező is sokkal változatosabb lett, a szerkezet felépítésétől és összetételétől függően.

$\mathrm{Az}$ európai normák megjelenése után lett kiadva a P100-1/2004, majd a jelenlegi P100-1/2006 (a SR EN 1998-1:2004 alapján), mely eredetileg egy átmeneti szabályozásként volt tekintve az Eurocode 8-as 2010-ben bekövetkező kötelező alkalmazásáig. Érdekes, hogy, bár a talajosztályozás az EC8-nak megfelelö volt, az épületfontossági osztályok a régebbi P.100-as szerint maradtak. A sarokperiódus ellenőrzési periódus lett, és új makrozónás térképek lettek szerkesztve. A szeizmikus szerkezeti vizsgálat a várható legnagyobb talajgyorsulást vette alapul, nem a földrengés intenzitását. Ennek megfelelően két újabb térképet tartalmaz a P100-1/2006, egy $a_{g} R$ referenciagyorsulási térképet (100 éves átlag visszatérési intervallumra), illetve egy periódusellenőrzési térképet (6. ábra). A szabvány háromféle $\beta$ görbét ír elő a három védelmi zónára, illetve egy negyedik fajtát a Bánát környéki sekély fészekmélységű földrengési területekre (ezek a satírozott részek az 6.a. ábrán). Ezek a dinamikus tényezők jellemzik a rugalmas válaszspektrum számítását:

$$
S_{e}(T)=a_{g} \cdot \beta(T) .
$$


ahol a $\beta(T)$ képlete a szerkezet kiszámolt periódusától függ, és ennek a $T_{B}, T_{C}$ és $T_{D^{-}}$ hez való viszonyulásától, így mindegyik $\beta$ görbe négy részből áll. A talaj rugalmas elmozdulását a

$$
S_{D e}(T)=S_{e}(T) \cdot\left[\frac{T}{2 \cdot \pi}\right]^{2}
$$

képlettel számolják a rugalmas válaszspektrumból, a földrengés okozta függőleges rugalmas rezgések értékét pedig az ellenőrzési periódus értékek módosítják, miszerint $T_{B v}=0,1 \cdot T_{C v}$, ahol a $T_{C v}=0,45 \cdot T_{C}$, illetve $T_{D v}=T_{D}$ [10]. A függőleges rugalmas válaszspektrum értéke ennek megfelelően: $S_{v e}$ $(T)=a_{v g} \cdot \beta_{v}(T)$ lesz és az $a_{v g}=0,7 \cdot a_{g}$ [10]. Az előbbiek értelmében lényegesen módosult a tervezési válaszspektrum is, amit az alábbi képletekkel lehet kiszámítani (ahol $q$ a viselkedési együttható, ami főleg a szerkezet duktilitásától függ):

$$
S_{d}(T)=a_{g} \cdot\left[1+\frac{\frac{\beta_{0}}{q}-1}{T_{B}} \cdot T\right],
$$

amikor $0<T \leq T_{B}$

$$
S_{d}(T)=a_{g} \cdot \frac{\beta(T)}{q}
$$

amikor $T>T_{B}$.

A P100-1/2006 szerint az épületek szeizmikus védelmét a tervezési, kivitelezési és hasznosítási elöírások betartásával lehet és kell megoldani, és nem az egyedi helyzetekben jelentkező különös következményekből kiindulva. Így az EC8 bevezetésével és a nemzeti alkalmazási dokumentum (SR EN 1998-1/NA) elkészítésével nem szünt meg a P100-1/2006 hatályossága, hanem továbbra is kötelező maradt a használata.

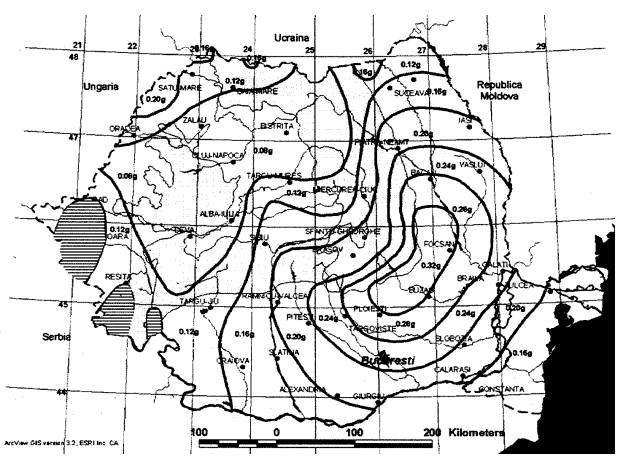

a)

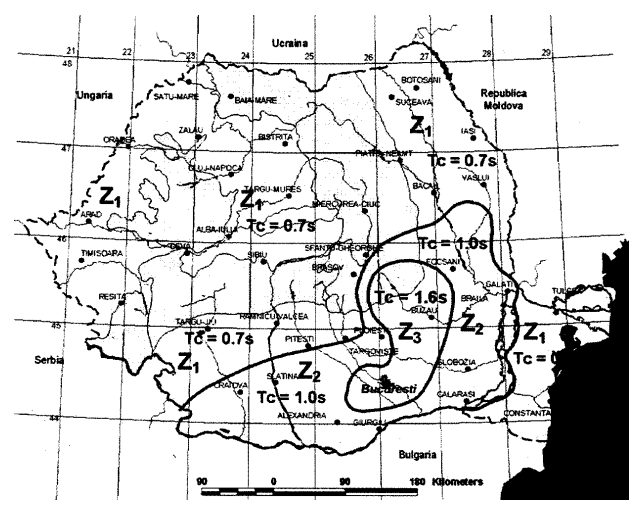

b)

6. ábra. $A$ P100-1/2006-ban megjelent $a_{g} R$ (PGA) térkép (a), valamint az ellenörzési periódus zónái (b).

2013. augusztus 8. -án lett jóvá hagyva a P100 legújabb változata (P100-1/2013), ami 2014. január elsejétől lesz hatályos [8]. Ez a szabvány még több újdonságot vezet be, a talajgyorsulásoknál figyelembe vett ÁVI (IMR) 225 évre lett emelve, a magas (DCH) és közepes (DCM) duktilitású osztályok mellé bevezeti az alacsonyt (DCL) is, elöírva a kimondott helyi duktilitás ellenőrzését (elfordulásszámítással) rudakként, illetve bevezet egy $\Omega$ hajlékonysági tényezőt, ami (még) nem szerepel az európai EC8-as szabványban. 


\section{Számítási példa és következ- tetések}

A szabványfejlődés egyszerü szemléltetéséhez egy 1970-ben tervezett ötszintes lakóház szerkezetét választottuk, mely az 1977-es földrengést minden károsodás nélkül átvészelte. Az épület cellaszerkezetes, ahol a öntött vasbeton falak, pillérek és gerendák alkotják a szerkezetet. A terv szerint elöre gyártott vasbeton födémelemeket használtak. Az alaprajz is mutatja, és a számítások is bizonyították, hogy az épületen csavaró hatást kelt a külpontosság miatt a földrengés. A kiszámolt önrezgési módok periódusai a 2. táblázatban vannak feltüntetve, mint látható, az $X$ irányú periódusok a jelentősebbek. Elhelyezésként a Szemerja negyedet választottuk Sepsiszentgyörgyön. A különféle szabványok szerint számított globális szeizmikus együtthatók szintén a 2. táblázatban vannak feltüntetve a könnyebb öszevetésért, a három lengésalak szerint.

$\mathrm{Az}$ újabb szabványok alkalmazásához már a talajgyorsulás referenciaértékét kell figyelembe venni. Az EC8 (SR EN 19981:2004) illetve a P100-1/2006 alkalmazása eltér a régebbi szabványok elöirásaitól, ezért az ezek alkalmazásából kapott értékeket nem foglaltuk táblázatba.

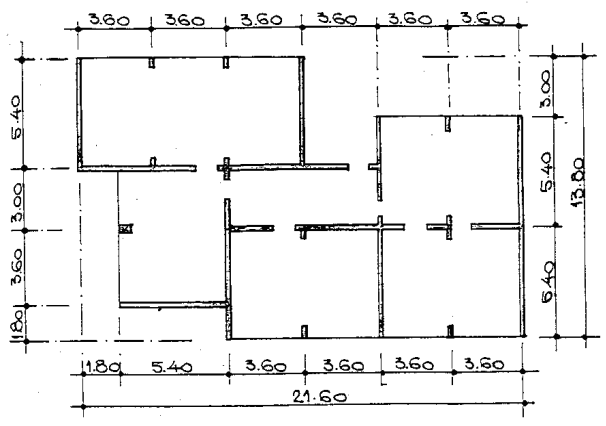

7. ábra. A példaként számolt lakóház alaprajzának vázlata.
A Sepsiszentgyörgynek megfelelö talajgyorsulás referenciaértéke $0,20 \mathrm{~g}$ a térkép

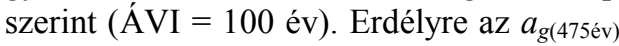
/ $a_{g(100 e ́ v)}=1,45$ érvényes, így a tényleges talajgyorsulás értéke $2,8449 \mathrm{~m} / \mathrm{s}^{2}$ lesz. Az $X$ irányban számolt rugalmas válaszspektrum globális szeizmikus együtthatója az első három lengésalakra 0,$473 ; 0,184$; illetve 0,102 lesz, összesítve 0,518 (mivel $\eta=$ $0,8165)$. Ha ezeket az értékeket elosztjuk a $q$ viselkedési tényezővel (ami DCM esetén 3.00 lesz), megkapjuk a tervezési válaszspektrum $X$ irányban érvényes globális szeizmikus együtthatóit: 0,$193 ; 0,078$ és 0,054 az első három lengésalakra, összesítve pedig 0,215 lesz. A fenti értékek természetesen más olyan helységek esetében is érvényesek, ahol a talajgyorsulás referenciaértéke és az ellenőrzési periódus megegyezik a Sepsiszentgyörgyével $\left(a_{g} R=0,20 \mathrm{~g}\right.$ és $Z_{l}: T_{C}=0,7 s$ ).

Könnyen észrevehetö, hogy a globális szeizmikus együttható értéke (ami a földrengési terheléssel egyenesen arányos) csökkenő tendenciát mutatott a P.13-63-as szabványtól a P.100-78-as szabványig. Ez azt jelenti, hogy az illető periódusban a müszaki-gazdasági fejlödés a szerkezetek kisebb anyagbefektetését ítélte fontosabbnak (a pénzmegtakarítást helyezte előtérbe) a szeizmikus kockázattal szemben. Ezt a szemléletet felborította az 1977-es földrengés tanulsága, ezért mutatnak növekvő tendenciát a globális szeizmikus együttható értékei a P.100-78-as szabványtól napjaink felé. A túlzott kockázatvállalás tehát nem bizonyult gazdaságosnak. A jelenlegi P100$1 / 2006$ alkalmazása is szigorúbb keretet teremt az EC8-hoz képest, és a soron következő P100-1/2013 még nagyobb szeizmikus biztonságot igér. 
2. táblázat. A lakóház önrezgési periódusai a fötengelyek szerint, valamint a régi szabványok szerint kiszámitott globális szeizmikus együttható értékei

\begin{tabular}{|c|c|c|c|c|c|c|c|c|c|}
\hline \multirow{3}{*}{$\begin{array}{r}\text { Lengésforma } \\
\text { Tengely- } \\
\text { irány } \\
T[s]\end{array}$} & \multicolumn{3}{|c|}{1} & \multicolumn{3}{|c|}{2} & \multicolumn{3}{|c|}{3} \\
\hline & $X$ & $Y$ & $\theta$ & $X$ & $Y$ & $\theta$ & $X$ & $Y$ & $\theta$ \\
\hline & 0,345 & 0,212 & 0,148 & 0,065 & 0,052 & 0,041 & 0,032 & 0,026 & 0,024 \\
\hline Szabvány: & \multicolumn{9}{|c|}{ A globális szeizmikus együtthatók értéke: } \\
\hline P.13-63 & & 0,0738 & & & 0,0144 & & & 0,0063 & \\
\hline P.13-70 & & 0,054 & & & 0,0106 & & & 0,0046 & \\
\hline P.100-78 & & 0,0736 & & & 0,0144 & & & 0,0063 & \\
\hline P.100-81 & & 0,0775 & & & 0,0144 & & & 0,0063 & \\
\hline P.100-90 & & 0,082 & & & 0,016 & & & 0,007 & \\
\hline
\end{tabular}

\section{Szakirodalmi hivatkozások}

[1] ASRO: SR EN 1998-1:2006, Eurocod 8: Proiectarea structurilor pentru rezistența la cutremur. Partea 1: Reguli generale, acțiuni seismice și reguli pentru clădiri. Asociaţia de Standardizare din România, București, 2006.

[2] CSEAL - MCInd: Normativ pentru proiectarea antiseismică a structurilor clădirilor de locuit şi social-culturale. P-13-63. București, 1963.

[3] CSEAL - MCInd: Normativ pentru proiectarea antiseismică a structurilor clădirilor de locuit și social-culturale. P-13-70. București, 1970.

[4] http://en.wikipedia.org/wiki/File:Pannonian Basin.svg

[5] ICCPDC: Normativ pentru proiectarea antiseismică a contrucțiilor de locuințe, socialculturale, agrozootehnice şi industriale. P100-78. București, 1978.

[6] ICCPDC: Normativ pentru proiectarea antiseismică a contrucțiilor de locuințe, socialculturale, agrozootehnice și industriale. P100-81. București, 1981.

[7] MLPAT: Normativ pentru proiectarea antiseismică a contrucțiilor de locuințe, socialculturale, agrozootehnice și industriale. P100-90. București, 1990.
[8] MDRAP: ORDIN MDRAP $n r$. 2465/08.08.2013 privind aprobarea reglementării tehnice , Cod de proiectare seismică - Partea I - Prevederi de proiectare pentru clădiri", indicativ $P 100$ - 1/2013. (http://www.mdrt.ro/userfiles/rt_OMDRAP\% 202465.pdf).

[9] Simon B.: Földrengések. Magyar Királyi Tudományos Társaság. Budapest, 1943.

[10] UTCB: Cod de proiectare seismică - Partea I-Prevederi de proiectare pentru clădiri, P100-1/2006. Universitatea Tehnică de Construcții București, București, 2006.

[11] Y. Ren et al.: Upper mantle structures beneath the Carpathian-Pannonian region: Implications for the geodynamics of continental collision. Earth and Planetary Science Letters 349-350, Elsevier B. V., 2012. 139152.

[12] Zsákai R.: A cunami elörejelzése. ABV Katasztrófavédelem, 67-77. (http://portal. zmne.hu/download/bjkmk/bsz/bszemle2012/1 /06_zsakairobert.pdf)

[13] Zsíros T.: A Kárpát-medence szeizmicitása és földrengésveszélyessége. Magyar földrengéskatalógus (456-1995). MTA GGKI, Budapest, 2000. 